\title{
Inhibition of receptor for advanced glycation end-products (RAGE) improves alveolar fluid clearance and lung injury in a mouse model of acute respiratory distress syndrome (ARDS)
}

\author{
R Blondonnet ${ }^{1,2^{*}}$, J Audard ${ }^{1,2}$, G Clairefond ${ }^{2}$, C Belville ${ }^{2}$, D Bouvier ${ }^{2,3}$, L Blanchon², V Sapin ${ }^{2,3}$, JM Constantin ${ }^{1,2}$, \\ M Jabaudon ${ }^{1,2}$
}

From ESICM LIVES 2015

Berlin, Germany. 3-7 October 2015

\section{Rationale}

The receptor for advanced glycation end-products (RAGE) is a transmembrane multipattern receptor abundantly expressed on the basal surface of alveolar type (AT) I cells. RAGE is implicated in ARDS-associated alveolar inflammation [1,2], but its precise roles in lung injury remain unknown. It has been shown recently that RAGE axis could impact alveolar fluid clearance (AFC) through the modulation of epithelial sodium channels [3]. In mouse models of sepsis and of ARDS, treatment with anti-RAGE monoclonal antibody decreased mortality, and treatment with recombinant soluble RAGE (sRAGE, acting as a decoy receptor) was associated with improved lung injury.

\section{Objective}

Using a murine model of ARDS, we evaluated whether RAGE modulation could regulate lung injury and AFC.

\section{Methods}

60 anesthetised male C57BL/6JTj mice were divided in 4 groups; 3 of them underwent orotracheal installation of hydrochloric acid (day 0). Among these acid-injured mice, some were intravenously treated with an antiRAGE monoclonal antibody ( $\mathrm{mAb}$ ) or intraperitoneal recombinant soluble RAGE (sRAGE). Mice from the Sham group underwent orotracheal instillation of saline and served as controls. At specified time-points (day 0 ,

${ }^{1} \mathrm{CHU}$ Clermont-Ferrand, Department of Anaesthesiology and Intensive Care Medicine, Clermont-Ferrand, France

Full list of author information is available at the end of the article
1, 2 and 4), lung injury was assessed after a 30-minute period of mechanical ventilation by analysis of blood gases, alvolar permeability index, bronchoalveolar lavage (BAL) fluid content in interleukin (IL)-6 and AFC. AFC was calculated detecting changes into alveolar protein levels over time.

\section{Results}

Acid-injured mice had higher permeability indexes, higher BAL IL-6 and marked hypoxemia on day 1 and 2 , as compared with sham animals. AFC rates and $\mathrm{PaO} 2 / \mathrm{FiO} 2$ ratios were higher in controls $(35 \% / 30 \mathrm{~min}$ and 281 [262-319], respectively) than in $\mathrm{HCl}$-injured mice on day 1 ( $8 \%$ and 181 [176-198], respectively, $\mathrm{P}<$ $0.0001)$ and day 2 (9\% and 186 [174-205], respectively, $\mathrm{P}<0.0001$ ).

RAGE inhibition restored AFC on day 1 in both mAbtreated $(8 \%$ versus $36 \%, \mathrm{p}=0.009)$ and sRAGE-treated $(8 \%$ versus $37 \% \mathrm{p}=0,009)$ mice. RAGE inhibition significantly improved both $\mathrm{PaO} 2 / \mathrm{FiO} 2$ ratio and permeability index on day 1 , day 2 , and anti-RAGE therapy could prevent increased BAL IL-6 levels on day 1 an day 2 in $\mathrm{HCl}$-treated mice.

\section{Discussion}

Our results support the efficacy of a RAGE inhibition strategy in improving AFC and lung injury in a translational mouse model of ARDS, and RAGE pathway may represent a therapeutic target during ARDS. Such findings should stimulate further research on the mechanistic links between RAGE pathway, AFC and lung alveolar injury and its resolution.

\section{SpringerOpen ${ }^{\circ}$}

(c) 2015 Blondonnet et al.; This is an Open Access article distributed under the terms of the Creative Commons Attribution License (http://creativecommons.org/licenses/by/4.0), which permits unrestricted use, distribution, and reproduction in any medium, provided the original work is properly cited. 

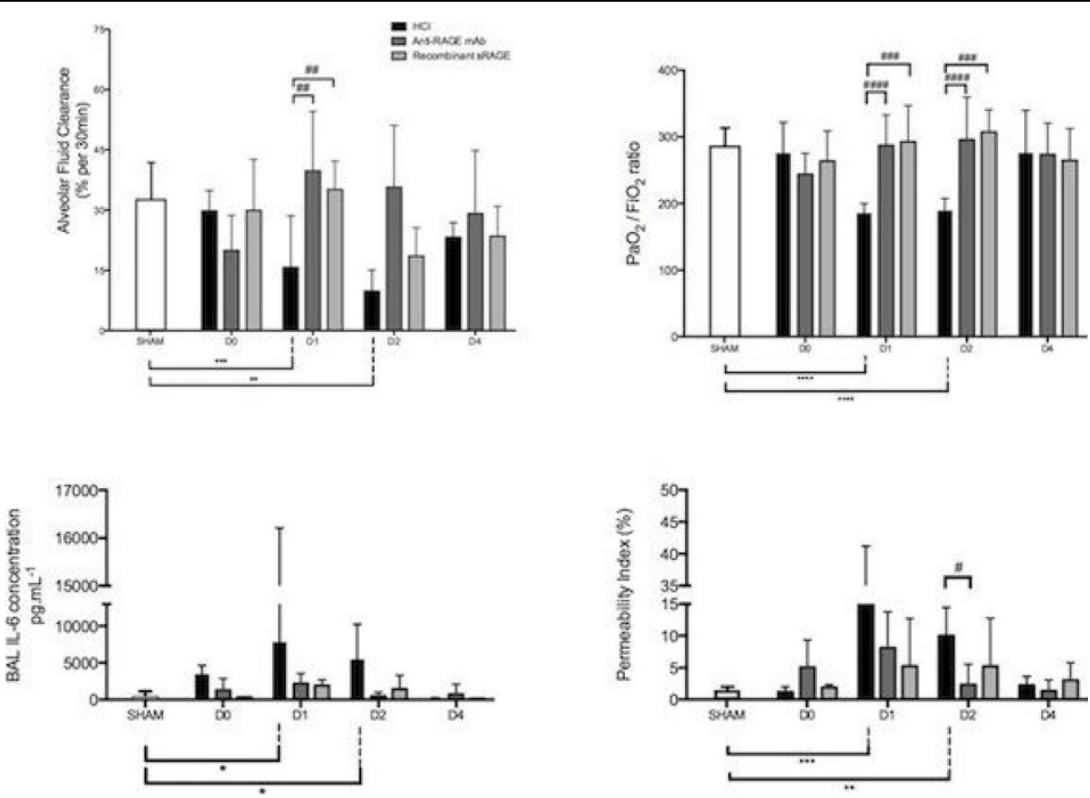

Figure 1 Mice lung injury over time.

\section{Authors' details}

${ }^{1} \mathrm{CHU}$ Clermont-Ferrand, Department of Anaesthesiology and Intensive Care Medicine, Clermont-Ferrand, France. ${ }^{2}$ Auvergne University, R2D2 - EA7281, Clermont-Ferrand, France. ${ }^{3} \mathrm{CHU}$ Clermont-Ferrand, Department of Medical Biochemistry and Molecular Biology, Clermont-Ferrand, France.

Published: 1 October 2015

\section{References}

1. Genes Cells 2004, 9(2):165-74

2. Crit Care Med 2011, 39(3):480-488.

3. Am J Respir Cell Mol Biol 2015, 52(1):75-87, Jan.

doi:10.1186/2197-425X-3-S1-A804

Cite this article as: Blondonnet et al: Inhibition of receptor for advanced glycation end-products (RAGE) improves alveolar fluid clearance and lung injury in a mouse model of acute respiratory distress syndrome (ARDS). Intensive Care Medicine Experimental 2015 3(Suppl 1):A804.

\section{Submit your manuscript to a SpringerOpen ${ }^{0}$ journal and benefit from:}

- Convenient online submission

- Rigorous peer review

- Immediate publication on acceptance

- Open access: articles freely available online

- High visibility within the field

- Retaining the copyright to your article 